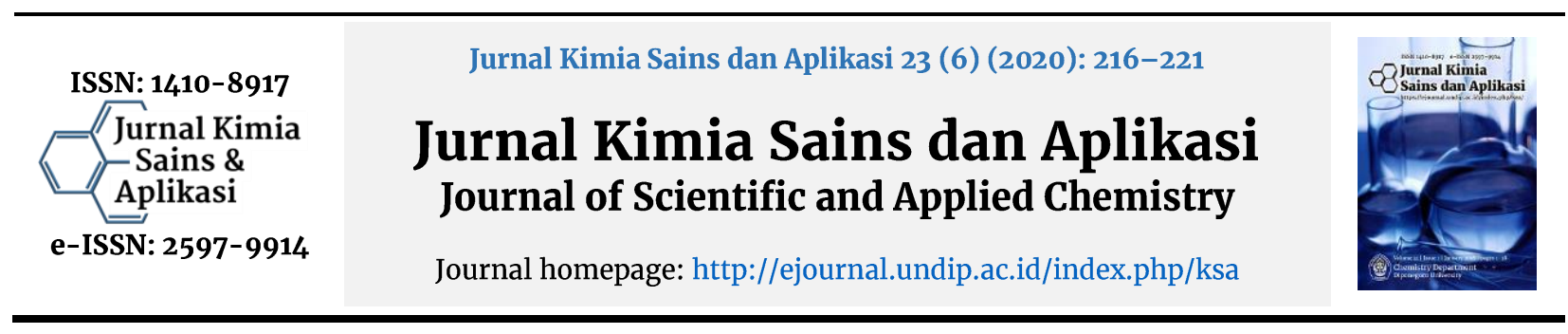

\title{
Characteristics of Edible Films Based on Corn Starch and Protein Isolates from Liquid Waste Extraction of Tofu Processing Industry
}

\author{
Rina Mirdayanti ${ }^{\mathrm{a}, 1, *}$, Amalia ${ }^{\mathrm{b}, 2}$ \\ ${ }^{\text {a }}$ Faculty of Teacher Training and Education, Abulyatama University, Aceh Besar, Indonesia \\ ${ }^{\mathrm{b}}$ Faculty of Engineering, Abulyatama University, Aceh Besar, Indonesia \\ Author emails: $\left(1,{ }^{*}\right)$ rinamirdani_fisika@abulyatama.ac.id; (2) amel.arsitektur@gmail.com
}

https://doi.org/10.14710/jksa.23.6.216-221

\begin{tabular}{l} 
Article Info \\
\hline Article history: \\
Received: $29^{\text {th }}$ October 2019 \\
Revised: $16^{\text {th }}$ April 2020 \\
Accepted: $15^{\text {th }}$ May 2020 \\
Online: $30^{\text {th }}$ June 2020 \\
\hline
\end{tabular}

Keywords:

liquid waste; protein isolates; edible film

\begin{abstract}
One factor contributing to the environment's waste is industrial activity both large and small scale. During this time, the waste collection is done by dumping it into a ditch and flowing it into the river, thus worsening environmental sanitation. This study aims to analyze the character of edible films of corn starch with protein isolates from the extraction of tofu processing industry wastewater. Samples were analyzed to determine the tensile strength and elongation of the resulting film by varying the amount of protein isolates, $0 \%, 3 \%, 5 \%, 7 \%$ and $9 \%$. The protein extraction process was carried out by centrifugation, while the water vapor transmission test was by the saucer method, while the identification of functional groups was through FTIR analysis. The results showed that the highest mechanical properties were obtained in the variation of $5 \%$ protein isolates with a value of 52.16 MPa and elongation of $38.4 \%$. For water vapor transmission rate (WVTR), film comparisons were made with $5 \%$ variation of protein isolates and $0 \%$ protein isolates. Films with $5 \%$ protein isolates have a smaller water absorption of $0.56 \%$, than films with $0 \%$ of $0.66 \%$. The value of water vapor transmission rate shows a very significant ratio, at $5 \%$ protein isolate of water vapor transmission at 0.00176 $\mathrm{g} / \mathrm{m}^{2} /$ day, much smaller than $0 \%$ protein isolate at $0.00864 \mathrm{~g} / \mathrm{m}^{2} /$ day. IR spectra showed the presence of amide groups I and II on the results of the analysis of protein isolates. While the globular structure of proteins is shown by the absorption of wave numbers 1667 and $1650 \mathrm{~cm}^{-1}$.
\end{abstract}

\section{Introduction}

Food industry waste in general does not endanger public health, because it is not seen directly in the transfer of disease. However, the high content of organic matter can act as a food source for microbial growth [1].The importance of knowledge about the properties of waste is very helpful in establishing effective waste collection and disposal methods. Biological subscriptions need to be applied to liquid waste containing dissolved organic solids [2].

Tofu industry in its processing process produces waste, both solid and liquid waste. Solid waste is produced from the screening and clumping process. Whereas the liquid waste is produced from washing, boiling, pressing and printing tofu. Therefore, the liquid waste produced is very high. Tofu liquid waste with characteristics containing high organic matter, temperatures reaching $40^{\circ} \mathrm{C}-46^{\circ} \mathrm{C}$, BOD levels $(6,000-$ $8,000 \mathrm{mg} / \mathrm{L}), \mathrm{COD}(7,500-14,000 \mathrm{mg} / \mathrm{L})$, TSS and $\mathrm{pH}$ are quite high as well. If it is discharged directly into water bodies, the liquid waste can pollute the environmental ecosystem. Based on this, it is very necessary a way of processing waste that aims to reduce the risk of pollution [3].

The study of waste, not only focuses on liquid waste, solid waste also has a very negative impact on environmental pollution, especially human health. In addition, solid waste is also a large volume and must be handled properly. Solid waste that mostly comes from domestic waste is plastic, including plastic packaging obtained from snack packets that are consumed daily. Food packaging plastics that are often found, are made 
from synthetic polymeric products derived from petrochemical materials which are non-renewable natural resources [4].

Many factors affect the increase in the volume of waste, one of which is human needs that cannot be separated from the use of plastic. Because limiting the use of plastic is considered impossible, one way that can be done is to replace plastic raw materials with natural polymer materials that are easily biodegradable in the environment and have good physical properties, so they can replace conventional plastics. Edible film is an alternative packaging material, where the main material for making edible film is a type of starch that is renewable and easily decomposes in the environment.

Cereals such as corn are a source of starch with a high starch content of $90 \%$, so corn starch is very potential to be used as the main ingredient in making edible films [5]. So far, the main ingredients sourced from starch have been widely used and research results show that the addition of cornstarch can increase the rate of water vapor transmission which is quite high and low mechanical properties. Therefore, hydrophobic nature of edible film is needed in order to reduce the rate of water vapor transmission in the resulting film. On this basis, it is necessary to do research on the characteristics of edible films that have protein isolate-strength extracted from tofu industry wastewater. Where the interaction between starch and protein isolates is expected to influence the rate of transmission of water vapor and produce characters from better edible films.

\section{Methodology}

\subsection{Material and Equipment}

The materials used in this study were tofu boiled water, which was obtained from the liquid waste of the tofu processing industry. The corn starch was commercially obtained, while other materials were sorbitol, distilled water, $\mathrm{NaOH}, \mathrm{HCl}$, potassium hydroxide and copper sulfate, all of which were technical grade and were obtained from the Chemistry research laboratory, MIPA, Syiah Kuala University. The instrument used to analyze the film was a spectrophotometer, WVTR petri dish method, tensile test equipment, hot plate, magnetic stirrer and oven.

\subsection{Extraction of Protein Isolates}

Tofu stew liquid waste was obtained from processing soybeans for tofu production in the city of Banda Aceh. A total of 2 liters of liquid waste was added with as much as $250 \mathrm{~mL}$ of water until the volume of the solution became 2.25 liters and then added $45 \% \mathrm{NaOH}$ solution with a ratio of $2: 1(\mathrm{v} / \mathrm{v})$. The mixture was heated at $80^{\circ} \mathrm{C}$, and stirred for 20 minutes. The stirred solution was filtered to remove pulp particles and centrifuged at $6000 \mathrm{rpm}$ for 30 minutes. Supernatant was decanted and precipitated using $0.1 \mathrm{~N} \mathrm{HCl}$. The precipitate formed was washed with distilled water until clean and centrifuged at a speed of $3000 \mathrm{rpm}$ for 15 minutes with 2 repetitions. The precipitate that has been clean was dried with a vacuum pump and sunlight to dry. The resulting protein isolate was mashed and stored in a closed container.

\subsection{Protein Testing}

$3 \mathrm{~mL}$ of protein solution was added with $5 \mathrm{~mL}$ of distilled water and then mixed with a solution of potassium hydroxide ( $1 \%$ ) at a ratio of $1: 1$. Next, 3 drops of copper sulfate solution ( $1 \%$ ) were added to the mixed solution. The color of the solution was then observed.

\subsection{Preparation of Edible Film}

Edible making of this film refers to Mirdayanti et al. [5] [5] with the following procedure. Extracted protein isolates were prepared according to the concentration of the treatment, i.e. $0 \%, 3 \%, 5 \%, 7 \%$ and $9 \%$ by weight of corn starch. Furthermore, 10 grams of corn starch were added to the protein isolate with $2 \mathrm{~mL}$ sorbitol and 140 $\mathrm{mL}$ distilled water while stirring using a magnetic stirrer for 30 minutes, with gelatinization temperatures of 80 degrees. Then the mixture was vacuum for 30 minutes. Then, the mixture was poured in a mold made of glass with a size of $20 \mathrm{~cm} \times 20 \mathrm{~cm}$ and flattened. Subsequently, the film mixture was dried in a $35^{\circ} \mathrm{C}$ drying oven for 24 hours. The dried film was then removed from the mold. The resulting edible film was wrapped in a plastic wrap and kept in a desiccator.

Table 1. Material composition in the preparation of Edible Film

\begin{tabular}{cccc}
\hline No & Protein Isolates $(\mathrm{g})$ & Cornstarch & Sorbitol \\
\hline 1. & 0 & $10 \mathrm{~g}$ & $2 \mathrm{~mL}$ \\
2. & 0.3 & $10 \mathrm{~g}$ & $2 \mathrm{~mL}$ \\
3. & 0.5 & $10 \mathrm{~g}$ & $2 \mathrm{~mL}$ \\
4. & 0.7 & $10 \mathrm{~g}$ & $2 \mathrm{~mL}$ \\
5. & 0.9 & $10 \mathrm{~g}$ & $2 \mathrm{~mL}$ \\
\hline
\end{tabular}

\section{Results and Discussion}

\subsection{Extraction of Protein Isolates}

This research was started by extracting protein isolates from wastewater from tofu processing using centrifugation methods. Extraction of protein isolates was made by centrifugation method using $45 \% \mathrm{NaOH}$ centrifuged at $6000 \mathrm{rpm}$ to remove pulp particles. The extraction product was precipitated using $0.1 \mathrm{~N} \mathrm{HCl}$. One $\mathrm{kg}$ of tofu waste produces 2.5 grams of protein isolate. From the extraction results, pure protein isolates were obtained.



Figure 1. (a). Results of Protein Isolate Extraction (b). Biuret Analysis of Protein Isolate Extraction Results 


\subsection{Visual Appearance of Edible Films}

Edible film sheets can be seen visually in Figure 2.
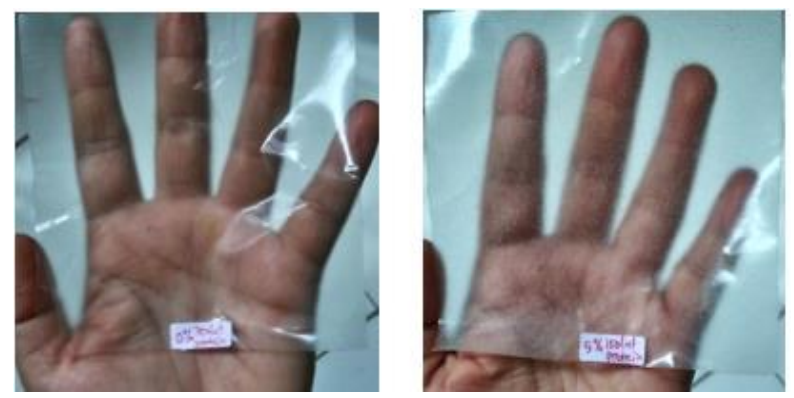

Figure 2. (a) Film with $0 \%$ Protein Isolate (b) Film with $5 \%$ Protein Isolate

Figure 1 shows the edible film produced by $0 \%$ and $5 \%$ protein isolates. Overall there were five variations of protein isolates from $0,3,5,7$ and $9 \%$ of the films produced. Gelatinization of the film is done by heating the protein. The gelatinization process occurs when starch granules consisting of amylose and amylopectin that have hydrogen bonds are given water and heated. Formation of edible film made from starch starts from the breaking of the granules and followed by the release of amylose which forms the tissue that surrounds the granules, so that there is an interaction between amylose one with another amylose. When there is an interaction between amylose, it is assumed that the structure of amylose molecules from one another is homogeneous. Likewise, with protein isolates, causing the film matrix to form more closely.

The dense film matrix is difficult to penetrate by water vapor. The mechanism of protein film formation occurs due to endothermic polymerization and protein denaturation due to heating followed by surface dehydration. The mechanism of polymerization involves disulfide molecules and hydrophobic bonds. Warming causes a three-dimensional protein structure between sulfhydryl and the hydrophobic side chain so that the non-folding protein chains will come closer to each other and are interconnected through disulfide and hydrophobic bonds. The addition of sorbitol as a plasticizer in the formation of edible films can reduce the film's permeability to oxygen, it is also able to reduce the agility of the film so that the tensile strength of the film increases.

In the five films produced mechanical properties were tested. It was found that films made from $5 \%$ protein isolates had the highest mechanical value. Then this film is further characterized. Films with the addition of protein isolates appear slightly more yellowish turbid and coarser structure due to the presence of hydrophobic protein grains that because it is not easily dissolved evenly in water. Protein isolates from liquid waste extraction containing globulin which have isoelectric point 4.1-4.6 g. Globulin settles at $\mathrm{pH}$ 4.1 while other proteins such as proteose, prolamin and albumin are soluble in water [6]. According to Koswara [1], soy protein mostly $(85-95 \%)$ consists of globulin which is the most important protein in soybeans. This protein is insoluble in water at its isoelectric point. In order for the mixture to be homogeneous and evenly distributed, it is necessary to physically reduce the size of the protein isolate powder and increase the heating temperature. Resulting in an interaction between starch and protein isolates in physics. Whereas the film without using protein isolates, the resulting film looks more transparent and is slightly thinner. Edible films derived from $0 \%$ and $5 \%$ protein isolates are presented in Figure 3.

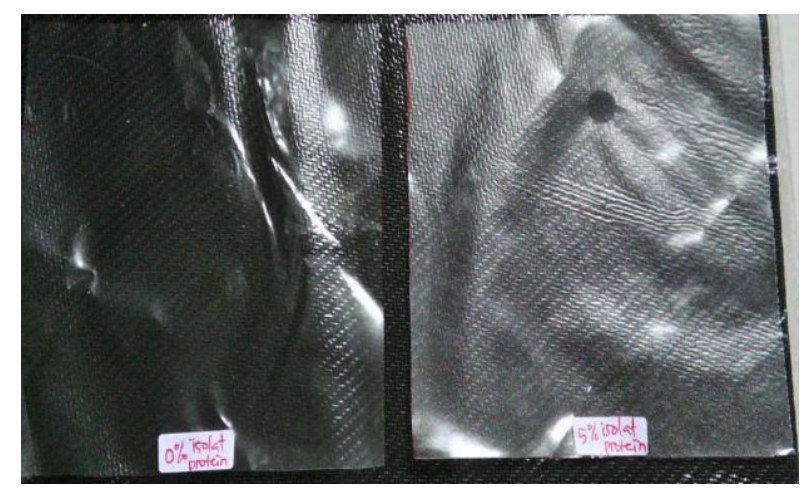

Figure 3. Edible Film Samples from Protein Isolates of (a) $0 \%$ and (b) $5 \%$

\subsection{Characters of Edible Films}

\subsubsection{Mechanical Properties}

Tensile strength and percent elongation are very important test parameters of edible film. High and low mechanical properties can affect the function of edible film as a food packaging material and as a protector of food products, both water vapor and gas.

Table 2. Mechanical Properties of Edible Films in various Protein Isolate compositions

\begin{tabular}{cccc}
\hline No & $\begin{array}{c}\text { Protein } \\
\text { Isolate }(\mathrm{g})\end{array}$ & $\begin{array}{c}\text { Tensile } \\
\text { Strength }(\mathrm{MPa})\end{array}$ & $\begin{array}{c}\text { Elongation } \\
(\%)\end{array}$ \\
\hline 1. & 0 & 49.44 & 36.28 \\
2. & 0.3 & 39.66 & 27.44 \\
3. & 0.5 & 52.16 & 38.4 \\
4. & 0.7 & 38.11 & 18 \\
5. & 0.9 & 41.44 & 19.25 \\
\hline
\end{tabular}

Table 2 shows the process of increasing tensile strength and elongation from $3 \%$ protein isolates to the preparation of $5 \%$ protein isolates, with the highest values being in protein isolates of $5 \%$, i.e., $52.16 \mathrm{MPa}$ and $38.4 \%$ respectively. The mechanical properties of edible film can be influenced by the thickness of the film due to differences in the concentration of protein isolates. This increase in tensile strength can also be affected by the presence of space between the layers (intercalation) affected by the polymer [7]. According to Gontard et al. [8], the mechanical strength of an edible film material is very dependent on the type of forming material, especially the nature of structural cohesion. Structural cohesion is a measure of the strength of the polymer to form molecular bonds between polymer chains [9].

Increased tensile strength is caused by increased interaction of protein isolates in the edible film matrix 
network. The increase in attractive forces between the molecules making up the edible film causes an increase in structural strength. This condition is related to the nature of proteins that produce dense structures through increased inter and intra molecular forces [10].

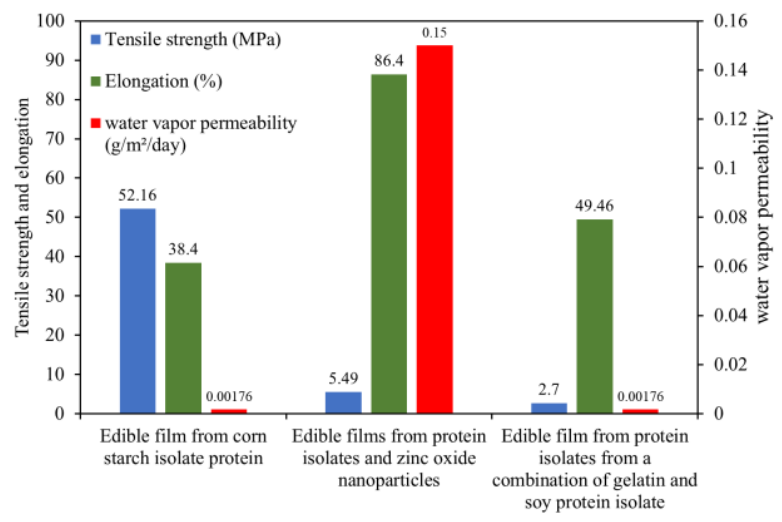

Figure 4. Comparison of research results of edible film based on protein isolates

From Figure 4 shows that the optimum tensile strength on edible corn starch films is the addition of $5 \%$ protein isolates, with a value of $52.16 \mathrm{MPa}$. This is in accordance with the standard tensile strength of biodegradable plastics in the range of $10-100 \mathrm{MPa}$. This is due to sorbitol plasticizer interfering with compactness of starch, where plasticizers will reduce intermolecular interactions and increase polymer mobility [11].

For the elongation value of edible film corn starch with the addition of $5 \%$ protein isolate with a value of $38.4 \%$. This value also approaches the biodegradable plastic standard range of $21-220 \%$. It was concluded that the formulation of protein isolates affected the product elongation. The character of edible films from tofu waste water processing protein isolates, when compared with previous studies, has better mechanical properties and approaches conventional plastic standards.

\subsubsection{Water Vapor Transmission Rate (WVTR)}

Water vapor permeability is carried out to analyze the rate of transmission of water vapor or gas. The water vapor transmission rate indicates the rate at which water vapor penetrates, or the film's ability to inhibit water transmission. So the permeability of the film to water vapor must be as low as possible [12]. In this study a comparison of the rate of transmission of water vapor from the film which has the best mechanical properties is a film that is prepared by adding $5 \%$ protein isolates and $0 \%$ protein isolates. From the test results it can be seen that the minimum water vapor transmission rate is at $5 \%$ protein isolate, that is $0.00176 \mathrm{~g} / \mathrm{m}^{2} /$ day while at $0 \%$ protein isolate, the water vapor transmission rate is higher at $0.00864 \mathrm{~g} / \mathrm{m}^{2} /$ day. These results indicate that films with $5 \%$ protein isolates produce lower water vapor transmission rates compared with films with $0 \%$ protein isolates. This condition is due to the presence of hydrophobic groups in protein isolate compounds that occur from a mixture of starch and protein isolates.

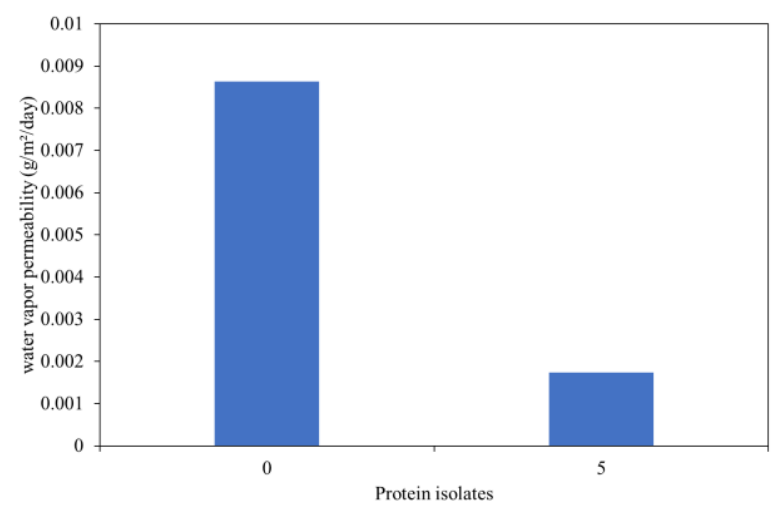

Figure 5. Water vapor transmission rate (WVTR)

According to Japanese International Standard (JIS) (1975), the value of the rate of transmission of water vapor from edible films is a maximum of $10 \mathrm{~g} \cdot \mathrm{m}^{-2}$.day ${ }^{-1}$ and elongation of at least $70 \%$ [13]. The results showed that the physical surface of the edible film with the preparation of $5 \%$ protein isolate was rough and there were spots of protein isolate that were not completely bound. In theory, the resulting protein isolate contains globulin which is a component that is non-polar and hydrophobic [2]. Therefore, the addition of protein isolates in the film matrix can reduce the rate of transmission of water vapor. The rate of water vapor transmission affects the ability of edible films to hold water vapor [8]. Edible films which have low water vapor transmission rates which are suitable for wrapping the product at high humidity [14].

\subsubsection{Water Adsorption}

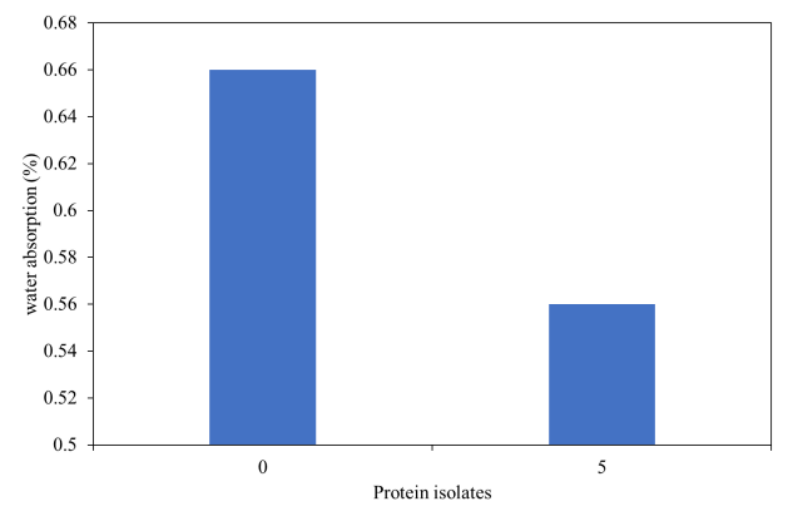

Figure 6. Water absorption from edible films

Water absorption occurs easily on the surface of a polysaccharide-based film, because of its hydrophilic nature [15]. The results showed that the physical absorption of edible film without the use of protein isolates or $0 \%$ protein isolates produced a slightly higher water absorption of $0.66 \%$, while the addition of $5 \%$ protein isolates produced films with smaller water absorption that is $0.56 \%$. These results indicate that the film with corn starch polysaccharide as a basis does not provide protection against water, but when the material is mixed with $5 \%$ protein isolates the water absorption is slightly lower. It is also influenced by soy protein which consists of a grabular protein mixture, around $90 \%$ of soy protein [14]. Grabulin protein has 
hydrophobic properties which causes the ability to absorb water to be slightly smaller.

\subsubsection{Functional Groups Analysis}

Films with a mixture of protein isolates and without protein isolates were characterized by FTIR to determine the existing functional groups.

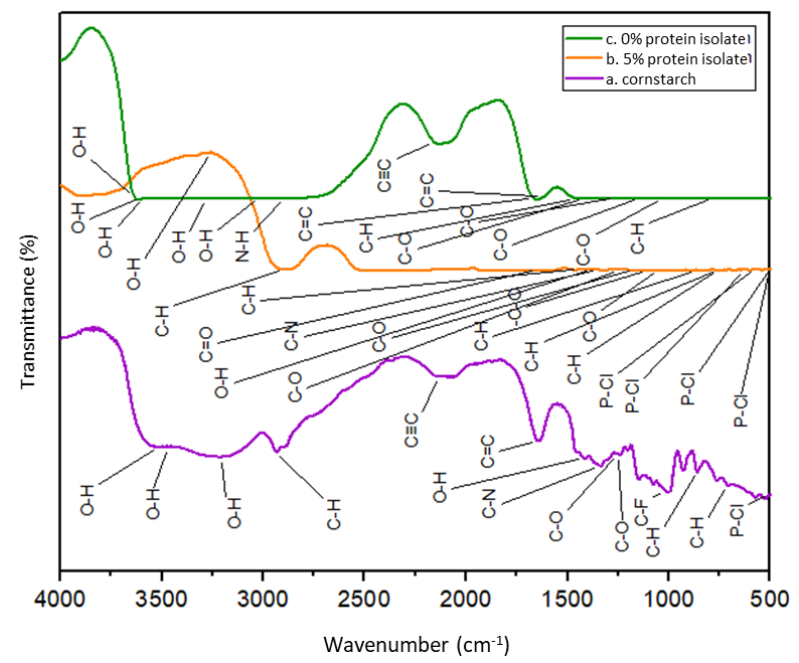

Figure 7. FTIR Spectra (a) Corn Starch (b) 5\% Protein Isolate (c) $0 \%$ Protein Isolate

Figure 7 shows the absorption band in the wave number area of $1900-1650 \mathrm{~cm}-1$ which indicates the presence of stretching $\mathrm{C}=\mathrm{O}$, that is, amide. According to Chen et al. [16], at wave numbers 1656 and $1535 \mathrm{~cm}-1$ there is an amide 1 group which is located in protein $\mathrm{C}=$ $\mathrm{O}$ and amide II is located in the binding $\mathrm{N}-\mathrm{H}$ and $\mathrm{C}-\mathrm{N}$ protein bonds. According to Kumosinski and Unruh [2], the presence of globular structures in proteins is indicated by the absorption of wave numbers in the regions of 1667 and $1650 \mathrm{~cm}-1$. This globular structure is also strongly influenced by the presence of amide I and II groups in protein isolates.

\subsubsection{Edible Film as Packaging for Food Products}

The resulting edible film was tested for packaging on snacks. Packaging with an edible coating is one of the relatively new food preservation techniques [8]. This packaging test is carried out for 24 hours. Sample tests were carried out with film layers without protein isolates and with film layers with the addition of $5 \%$ protein isolates.

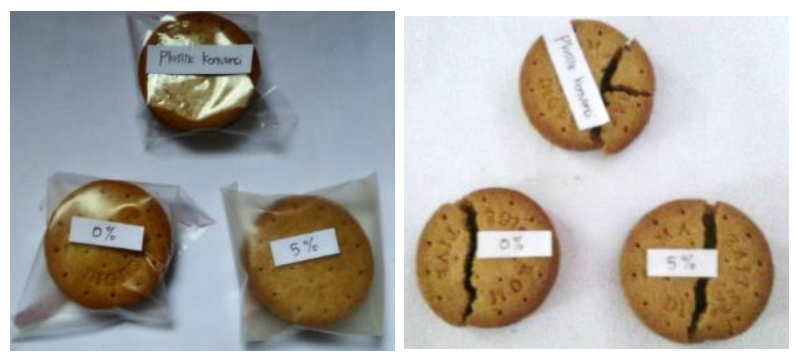

Figure 8. Snack packaging using edible film compared to conventional plastic

The test results show that the resulting edible film can be used as food wrappers. Food conditions for 24 hours of testing showed that the structure of the food or product quality was in good condition, the ability of the envelope of $0 \%$ edible film and $5 \%$ protein isolate was the same for each sample. Likewise, the ability to protect food from outside air with good conditions. Food becomes soft after 18 hours of testing. Whereas the wrapping test with conventional plastic, the quality of the food was slightly better, as seen from the tougher food structure.

\section{Conclusions}

This research succeeded in preparing and characterizing edible films made from corn starch with protein isolate-reinforced corn from the liquid waste extraction from tofu processing industry. Protein isolates can be used as ingredients in the preparation of edible films. The addition of $5 \%$ protein isolate increased the tensile strength by $52.16 \mathrm{MPa}$ and the extension by $38.4 \%$. The results showed that the addition of $5 \%$ protein isolates reduced the water vapor permeability by a value of $0.00174 \mathrm{~g} / \mathrm{m}^{2} /$ day and water absorption by $0.56 \%$. The results of this study approach the standard range of biodegradable plastics, so that it can be applied as a food packaging.

\section{Acknowledgments}

The authors would like to thank profusely to Abulyatama University and Kemenristek Dikti for funding support. This research was fully funded by the Hibah Dikti Penelitian Dosen Pemula with a contract number: 119 / SP2H / LT / DRPM / 2019.

\section{References}

[1] Sutrisno Koswara, Teknologi Pengolahan Kedelai (Teori dan Praktek), in: EbookPangan. com, 2009,

[2] Thomas F. Kumosinski, Joseph J. Unruh, Quantitation of the global secondary structure of globular proteins by FTIR spectroscopy: Comparison with X-ray crystallographic structure, Talanta, 43, 2, (1996), 199-219

https://doi.org/10.1016/0039-9140(95)01726-7

[3] Attila E. Pavlath, William Orts, Edible Films and Coatings: Why, What, and How?, in: K.C. Huber, M.E. Embuscado (Eds.) Edible Films and Coatings for Food Applications, Springer New York, New York, NY, 2009, pp. 1-23 https://doi.org/10.1007/978-0-387-92824-1_1

[4] Nanan Nurdjannah, Sri Usmiati, Isolasi dan Karakterisasi Protein Ampas Tahu, Jurnal Penelitian Pascapanen Pertanian, 3, 2, (2019), 83-95 http://dx.doi.org/10.21082/jpasca.v3n2.2006.83-95

[5] Rina Mirdayanti, Basuki Wirjosentono, Eddy Marlianto, Analisis Edible Film dari Campuran Keratin dan Pati Jagung, Jurnal Serambi Engineering, 3, 2, (2018), 316-325

https://doi.org/10.32672/jse.v3i2.715

[6] Agung Wahyu Pamungkas, Agus Slamet, Pengolahan Tipikal Instalasi Pengolahan Air Limbah Industri Tahu di Kota Surabaya, Jurnal Teknik ITS, 6, 2, (2017), D123-D128 http://dx.doi.org/10.12962/j23373539.v6i2.24585

[7] Jong-Whan Rhim, Jun-Ho Lee, Hyo-Sup Kwak, Mechanical and water barrier properties of soy 
protein and clay mineral composite films, Food Science and Biotechnology, 14, 1, (2005), 112-116

[8] Nathalie Gontard, Stéphane Guilbert, Jean-Louis Cuq, Edible Wheat Gluten Films: Influence of the Main Process Variables on Film Properties using Response Surface Methodology, Journal of Food Science, 57, 1, (1992), 190-195

https://doi.org/10.1111/j.1365-2621.1992.tb05453.x

[9] Fakhrieh Vojdani, J. Antonio Torres, Potassium Sorbate Permeability of Methylcellulose and Hydroxypropyl Methylcellulose Coatings: Effect of Fatty Acids, Journal of Food Science, 55, 3, (1990), 841-846

https://doi.org/10.1111/j.1365-2621.1990.tb05244.x

[10] Seung Yong Cho, Chul Rhee, Mechanical properties and water vapor permeability of edible films made from fractionated soy proteins with ultrafiltration, LWT - Food Science and Technology, 37, 8, (2004), 833839 https://doi.org/10.1016/j.lwt.2004.03.009

[11] Maria Rodríguez, Javier Osés, Khalid Ziani, Juan I. Maté, Combined effect of plasticizers and surfactants on the physical properties of starch based edible films, Food Research International, 39, 8, (2006), 840-846

https://doi.org/10.1016/j.foodres.2006.04.002

[12] Muhamad Hasdar, Yuny Erwanto, Suharjono Triatmojo, Karakteristik edible film yang diproduksi dari kombinasi gelatin kulit kaki ayam dan soy protein isolate, Buletin Peternakan, 35, 3, (2011), 188196

https://doi.org/10.21059/buletinpeternak.v35i3.1092

[13] Budi Santoso, Zuhara Hilda, Gatot Priyanto, Rindit Pambayun, Perbaikan Sifat Laju Transmisi Uap Air dan Antibakteri Edible Film dengan Menggunakan Minyak Sawit dan Jeruk Kunci, agriTECH, 37, 3, (2017), 263-270 https://doi.org/10.22146/agritech.31539

[14] H. Deanti, J. M. Hulu, A. Setyaji, R. N. Eliyanti, K. Aliya, E. N. Dewi, The Quality of Edible Film Made from Nile Tilapia (Oreochromis niloticus) Skin Gelatin with Addition of Different Type Seaweed Hydrocolloid, IOP Conference Series: Earth and Environmental Science, 116, (2018), 012062 https://doi.org/10.1088/1755-1315/116/1/012062

[15] Imawati Eka Putri, Nugraha Edhi Suyatma, Film Edibel Antibakteri Berbasis Isolat Protein Kedelai dengan Ekstrak Kunyit dan Nanopartikel Seng Oksida, Jurnal Teknologi \& Industri Pangan, 29, 1, (2018), 85-92 https://doi.org/10.6066/jtip.2018.29.1.85

[16]Xiangyan Chen, Yi Ru, Fengliang Chen, Xianchang Wang, Xiaoyan Zhao, Qiang Ao, FTIR spectroscopic characterization of soy proteins obtained through AOT reverse micelles, Food Hydrocolloids, 31, 2, (2013), 435-437 https://doi.org/10.1016/j.foodhyd.2012.11.017 